\title{
BISNIS JUAL BELI ONLINE (ONLINE SHOP) DALAM HUKUM ISLAM DAN HUKUM NEGARA
}

\author{
Tira Nur Fitria \\ STIE-AAS Surakarta \\ Email: tiranurfitria@gmail.com
}

\begin{abstract}
This study aims to find out about online shop (online business shop) in Islamic view (Islamic law). This research is qualitative descriptive. This study included literature to examine the written sources such as scientific journals, books referesni, literature, encyclopedias, scientific articles, scientific papers and other sources that are relevant and related to the object being studied. As for the object of study of this research is in the form of texts or writings that describe and explain about the business / online shop (online shopping), which become popular in Indonesia. Results from this study is Islam do business through online is allowed in accordance with Islamic Shari'a. While there are elements of usury, injustice, menopoli and fraud. Prophet hinted that buying and selling is lawful while consensual (Antaradhin), for sale or through an online business as having a positive impact because it is practical, fast, and easy for the buyer. If the business by via online not in accordance with the terms and conditions described above, online business is not allowed.
\end{abstract}

Keywords: Buying and selling, online, Islamic economy

\section{Pendahuluan}

Muamalat adalah tukar menukar barang, jasa atau sesuatu yang memberi manfaat dengan tata cara yang ditentukan. Termasuk dalam muamalat yakni jual beli. Jual beli adalah bentuk dasar dari kegiatan ekonomi manusia dan merupakan aktivitas yang sangat dianjurkan dalam ajaran Islam. Bahkan, Rasulullah SAW sendiri pun telah menyatakan bahwa 9 dari 10 pintu rezeki adalah melalui pintu berdagang (al-hadits). Artinya, melalui jalan perdagangan (jual beli) inilah, pintu-pintu rezeki akan dapat dibuka sehingga karunia Allah terpancar daripadanya. Jual beli merupakan sesuatu yang diperbolehkan.

Dalam Qur' an Surat Al Baqoroh ayat 275, Allah menegaskan bahwa: "...Allah menghalalkan jual beli dan mengharamkan riba...". Hal yang menarik dari ayat tersebut adalah adanya pelarangan riba yang didahului oleh penghalalan jual beli, dengan catatan selama dilakukan dengan benar sesuai dengan tuntunan ajaran Islam.

Dalil di atas dimaksudkan untuk transaksi offline. Sekarang bagaimana dengan transaksi online di saat sekarang ini? Ketika kita bicara tentang bisnis online, banyak sekali macam dan jenisnya. Namun demikian secara garis besar bisa di artikan sebagai jual beli barang dan jasa melalui media elektronik, khususnya melalui internet atau secara online.

Salah satu contoh adalah penjualan produk/barang secara online melalui internet seperti yang dilakukan Lazada, Tokopedia, Buka Lapak, Blibli, Elevania, Shopee dll. Dalam bisnis ini, dukungan dan pelayanan terhadap konsumen menggunakan situs atau website tertentu via laptop atau computer; ataupun aplikasi yang dapat diunduh dari gadget atau ponsel via playstore.

Dewasa ini, kita tak dapat mengelak bahwa fenomena jual beli online telah tumbuh dan menjamur ditengah-tengah kehidupan kita sehari-hari. Mulai dari penjualan pakaian 
jadi, sepatu, tas, buku, dll. Lantas bagaimanakah hukum jual beli online dalam perspektif islam? Dan bagaimanakah jual beli online yang diperbolehkan (halal) dalam perspektif islam? Jawaban-jawaban atas pertanyaan tersebut akan kami ulas satu persatu dalam artikel ini sehingga nantinya memunculkan suatu kesimpulan yang tepat dan dapat diterima oleh para pembaca dengan bahasa yang mudah dipahami. Sehingga pengetahuan pembaca akan hukum jual beli online dalam perspektif islam lebih jelas.

\section{PEMBAHASAN}

\section{Jual Beli}

Perkataan jual beli terdiri dari dua suku kata yaitu "Jual dan Beli". Sebenarnya kata "Jual" dan "Beli" mempunyai arti yang satu sama lainnya bertolak belakang. Kata "Jual" menunjukkan bahwa adanya perbuatan menjual, sedangkan "Beli" adalah adanya perbuatan membeli (Suhrawardi, 200: 128). Jual beli menurut bahasa artinya menukar sesuatu dengan sesuatu, sedangkan menurut syar'i artinya menukar harta dengan harta menurut cara-cara tertentu. Nabi Muhammad SAW bersabda yang artinya:

"dari Rifa'ah r.a bahwasannya Nabi Muhammad SAW di tanya : "Pencarian apakah yang paling baik?". Beliau menjawab, "Ialah orang yang bekerja dengan tangannya, dan tiap-tiap jual beli yang bersih". (H.R. AlBazar dan disahkan oleh Hakim).

Selain itu jual beli telah diridhoi Allah dan Rosul-Nya. Sebab jual beli berbeda dengan riba. Allah telah menghalalkan jual beli dan mengharamkan riba. Menurut Tho'in (2016: 64) bahwa riba telah disepakati keharamannya oleh seluruh ulama bahkan oleh seluruh syariat langit, dengan kata lain riba tidak hanya diharamkan oleh agama Islam saja, tetapi agama-agama samawi yang lainpun juga mengharamkannya.
Selanjutnya Volmar sebagaimana dikutip oleh Suryodiningrat (1996: 14) mengatakan bahwa jual-beli adalah pihak yang satu penjual (verkopen) mengikatkan dirinya kepada pihak lainnya pembeli (loper) untuk memindah tangankan suatu benda dalam eigendom dengan memperoleh pembayaran dari orang yang disebut terakhir, sejumlah tertentu, berwujud uang.

Jual beli adalah suatu kegiatan tukar menukar barang dengan barang lain dengan tata cara tertentu. Termasuk dalam hal ini adalah jasa dan juga penggunaan alat tukar seperti uang. Jual beli itu sendiri yaitu: tukar menukar barang dengan barang dengan uang dengan jalan melepaskan hak milik dari yang satu kepada yang lainatas dasar saling merelakan (Hidayat, 2015: 9).

Jual beli dapat diadakan secara lisan, dapat pula secara tertulis (Pasal 1458 KUHPdt). Jika diadakan secara lisan, maka selalu didukung oleh alat bukti tertulis, misalnya faktur penjualan, kuitansi pembayaran. Jika dilakukan secara tertulis, perjanjian dapat dibuat dalam bentuk akta otentik di muka notaris, dapat pula dalam bentuk akta di bawah tangan yang dibuat oleh pihak-pihak sendiri. Demikian juga cara melakukan pembayaran dan penyerahan barang. Pembayaran harga dilakukan di tempat dan pada waktu yang ditetapkan dalam perjanjian (Pasal 1513 KUHPdt), secara tunai atau dengan surat berharga melalui bank. Sedangkan penyerahan barang dilakukan di tempat di mana barang itu berada, kecuali jika diperjanjikan lain (Pasal 1477 KUHPdt). (Abdul Kadir, 1999: 317-318)

Dari beberapa definisi di atas dipahami bahwa jual beli ialah perjanjian tukar menukar benda atau barang yang mempunyai nilai secara ridha di antara kedua belah pihak, yang satu menerima benda-benda dan pihak 
lain menerimanya sesuai dengan perjanjian atau ketentuan yang telah dibenarkan syara' dan disepakati. Adapun rukun jual beli adalah: 1) Ada penjual dan pembeli yang keduanya harus berakal sehat, atas kemauan sendiri, dewasa/baligh dan tidak mubadzir alias tidak sedang boros. 2) Ada barang atau jasa yang diperjualbelikan dan barang penukar seperti uang, dinar emas, dirham perak, barang atau jasa. Untuk barang yang tidak terlihat karena mungkin di tempat lain namanya salam. 3) Ada ijab qabul yaitu adalah ucapan transaksi antara yang menjual dan yang membeli (penjual dan pembeli).

\section{Jual Beli di Zaman Rosulullah}

Berdagang atau berbisnis merupakan aktivitas yang sangat dianjurkan dalam ajaran Islam. Bahkan Rasulullah SAW sendiri pun saat remaja sudah memulai untuk berdagang ke negeri Syam. Jual beli merupakan sesuatu yang diperbolehkan, dengan catatan selama dilakukan dengan benar sesuai dengan tuntunan ajaran Islam.

Dahulunya sistem jual beli kita kenal dengan istilah sistem barter dan transaksi perdagangan dilakukan dengan cara langsung dan berhadap-hadapan, namun dalam perkembangannya di zaman kontemporer ini dimana teknologi semakin canggih, orang bisa melakukan perniagaan dan transaksi melalui teknologi yang canggih atau biasa disebut dengan jual beli online. Dan dalam perkembangan zaman saat ini, kita tak dapat mengelak bahwa fenomena jual beli online telah tumbuh dan menjamur ditengah-tengah kehidupan kita sehari-hari. Mulai dari penjualan pakaian jadi, sepatu, tas, buku, dll.

Jual dan beli sudah di kenal semenjak dari jaman kenabian, begitu juga kebanyakan dari para istri-istri nabi berprovesi sebagai pedagang, contohnya siti khodijah istri Nabi
Muhammad SAW juga seorang pedagang yang sukses. Adapun jual beli atau muamalat di dalam islam, ada syari'at atau aturan-aturan yang harus di penuhi dan di jalankan oleh pelaku dagang maupun pembeli.

Muhammad bin Abil Mujalid mengisahkan:

"Pada suatu hari aku diutus oleh Abdullah bin Syaddad dan Abu Burdah untuk bertanya kepada sahabat Abdullah bin Aufa. Mereka berdua berpesan: bertanyalah kepadanya, apakah dahulu sahabat Nabi semasa hidup Nabi memesan gandum dengan pembayaran lunas di muka? Ketika sahabat Abdullah ditanya demikian, beliau menjawab: Dahulu kami memesan gandum, sya'ir (satu jenis gandum dengan mutu rendah), dan minyak zaitun dalam takaran, dan tempo penyerahan yang disepakati dari para pedagang Negeri Syam. Muhammad bin Abil Mujalid kembali bertanya: Apakah kalian memesan langsung dari para pemilik ladang? Abdullah bin Aufa kembali menjawab: Kami tidak bertanya kepada mereka, tentang hal itu." (HR. AlBukhari)

Jaman dahulu ketika orang membutuhkan sesuatu/barang maka mereka harus menukarnya dengan barang (barter), kemudian berkembang dengan memakai uang untuk membeli barang tersebut. Sekarang dengan seiringnya waktu yang terus berjalan dan ilmu teknologi yang semakin canggih maka di kenal jual beli dengan cara online dan kedepan apapun bentuk jual beli, menurut islam boleh dan halal selama memenuhi aturan-aturan yang telah di tetapkan dalam syari'at islam.

Bisnis, berdagang, atau berjualan sangat dianjurkan oleh Nabi Muhammad SAW. Seperti yang disampaikan beliau dalam hadis bahwa 9 dari 10 pintu rezeki berada dalam dunia bisnis. Meski demikian perdagangan maupun bisnis yang dilakukan harus dalam koridor ajaran Islam. Mengenai bisnis online, ada sebuah hadis yang mengarah padanya. 
"Janganlah kau membeli ikan di dalam air, karena biasanya mengandung kecurangan" (Hadis riwayat Ahmad bin Hambal dan Al Bayhaqi dari Ibn Mas'ud).

Allah swt mensyariatkan jual beli sebagai pemberian keluangan dan keleluasaan kepada hamba-hamba-Nya, karena semua manusia secara pribadi mempunyai kebutuhan berupa sandang, pangan, dan papan.Kebutuhan seperti ini tak pernah putus selama manusia masih hidup. Tak seorang pun dapat memenuhi hajat hidupnya sendiri, karena itu manusia di tuntut berhubungan satu sama lainnya. Dalam hubungan ini, taka da satu hal pun yang lebih sempurna daripada saling tukar, dimana seorang memberikan apa yang ia miliki untuk kemudian ia memperoleh sesuatu yang berguna dari orang lain sesuai dengan kebutuhannya masing-masing. (Ihsan, 2008: 89).

\section{Jual Beli Online (Bisnis Online)}

Jual beli online di artikan sebagai jual beli barang dan jasa melalui media elektronik, khususnya melalui internet atau secara online. Salah satu contoh adalah penjualan produk secara online melalui internet seperti yang dilakukan oleh bukalapak.com, berniaga.com, tokobagus.com, lazada.com, kaskus, olx.com, dll.

Menurut Suherman (2002: 179), jual beli via internet yaitu" (sebuah akad jual beli yang dilakukan dengan menggunakan sarana eletronik (internet) baik berupa barang maupun berupa jasa)". Atau jual beli via internet adalah "akad yang disepakati dengan menentukan ciri-ciri tertentu dengan membayar harganya terlebih dahulu sedangkan barangnya diserahkan kemudian" (Urnomo, 2000: 4).

Berdasarkan pengertian di atas dapat disimpulkan bahwa jual beli via internet adalah jual beli yang terjadi dimedia elektronik, yang mana transaksi jual beli tidak mengharuskan penjual dan pembeli bertemu secara langsung atau saling menatap muka secara langsung, dengan menentukan ciri-ciri, jenis barang, sedangkan untuk harga nya dibayar terlebih dahulu baru diserahkan barangnya. Sedangkan karakteristik bisnis online, yaitu:

1) Terjadinya transaksi antara dua belah pihak;

2) Adanya pertukaran barang, jasa, atau informasi;

3) Internet merupakan media utama dalam proses atau mekanisme akad tersebut.

Dari karakteristik di atas, bisa di lihat bahwa yang membedakan bisnis online dengan bisnis offline yaitu proses transaksi (akad) dan media utama dalam proses tersebut. Akad merupakan unsur penting dalam suatu bisnis. Secara umum, bisnis dalam Islam menjelaskan adanya transaksi yang bersifat fisik, dengan menghadirkan benda tersebut ketika transaksi, atau tanpa menghadirkan benda yang dipesan, tetapi dengan ketentuan harus dinyatakan sifat benda secara konkret, baik diserahkan langsung atau diserahkan kemudian sampai batas waktu tertentu, seperti dalam transaksi as-salam dan transaksi al-istishna. Transaksi as-salam merupakan bentuk transaksi dengan sistem pembayaran secara tunai/disegerakan tetapi penyerahan barang ditangguhkan. Sedang transaksi al-istishna merupakan bentuk transaksi dengan sistem pembayaran secara disegerakan atau secara ditangguhkan sesuai kesepakatan dan penyerahan barang yang ditangguhkan.

Ada dua jenis komoditi yang menjadi objek transaksi online, yaitu barang/jasa non digital dan digital. Transaksi online untuk komoditi non digital, pada dasarnya tidak 
memiliki perbedaan dengan transaksi assalam dan barangnya harus sesuai dengan apa yang telah disifati ketika bertransaksi. Sedangkan komoditi digital seperti ebook, software, script, data, yang dalam bentuk file (bukan CD) diserahkan secara langsung kepada konsumen, baik melalui email ataupun download. Hal ini tidak sama dengan transaksi as-salam tapi seperti transaksi jual beli biasa.

\section{Alur Jual Beli Online}

Skema dasar dari bisnis online adalah:
a. Terjadinya transaksi antar dua pihak.
b. Adanya pertukaran barang, jasa maupun informasi.
c. Internet adalah media utama dalam proses jual beli (ijab-qabul).

Ada dua jenis ijab-qabul yaitu: 1) Sesuai perjanjian, dimana pembayaran dilakukan dengan tunai sebelum barang dikirim. 2) Al Istisna, yaitu bentuk pembayaran yang menunggu hingga barang dikirim.

Sama seperti bisnis pada umumnya, bisnis online dalam ekonomi syariah juga terbagi dalam yang halal dan haram, legal atau illegal. Bisnis online yang diharamkan yaitu bisnis judi online, perdagangan barangbarang terlarang seperti narkoba, video porno, barang yang melanggar hak cipta, senjata dan benda lain yang tidak memiliki manfaat. Intinya, bisnis online adalah bisnis berdasarkan muamalah. Bisnis online diizinkan (Ibahah) selama bisnis tersebut tidak mengandung elemen yang dilarang. Transaksi penjualan online dimana barang hanya berdasar pada deskripsi yang disediakan oleh penjual dianggap sah, namun jika deskripsi barang tidak sesuai maka pembeli memiliki hak khiyar yang memperbolehkan pembeli untuk meneruskan pembelian atau membatalkannya.

\section{Perkembangan Bisnis Online di Indonesia}

Dengan semakin banyaknya pengguna internet di seluruh dunia, bisnis online menjadi salah satu hal yang menjamur akhirakhir ini. Di Indonesia sendiri banyak sekali terdapat bisnis online, baik dalam skala kecil hingga besar. Dengan menjamurnya bisnis online yang mengandalkan kepercayaan antara pembeli dan pedagang ini, tingkat penipuan dalam bisnis online pun semakin meningkat.

Di Indonesia sendiri, keberadaan bisnis online syariah (bisnis berbasis syariat) bisa dikatakan mulai berkembang. Kini semakin banyak masyarakat yang sadar akan pentingnya bisnis yang bersih, jujur dan sesuai dengan hukum Islam. Keberadaan bisnis online syariah ini juga tak terlepas dari peran perbankan syariah yang tumbuh secara positif di Indonesia. Sistem ekonomi syariah yang kini tengah populer di masyarakat membuat banyak orang beralih ke bisnis online yang sesuai dengan aturan Islam ini. Lalu bagaimana pandangan Islam mengenai bisnis ini?

Pada dasarnya, bisnis online ini sama dengan bisnis offline seperti biasanya. Yang membedakan keduanya hanya lokasi atau tempat bisnis itu dijalankan. Dalam bisnis offline, terdapat toko atau tempat tetap yang digunakan untuk menjual barang atau jasa, sedangkan bisnis online menggunakan media internet sebagai tempat berjualan sekaligus media berpromosi. Antara pembeli dan penjual saling tak tatap muka dan transaksi dilakukan atas dasar kepercayaan.

\section{Kelebihan dan Kekurangan Jual Beli Online (Bisnis Online)}

Adapun keuntungan yang di dapat oleh konsumen antara lain : 
1. Pembeli tidak perlu mendatangi toko untuk mendapatkan barang, cukup terkoneksi dengan Internet, pilih barang dan selanjutnya melakukan pemesanan barang, dan barang akan di antar kerumah.

2. Menghemat waktu dan biaya transportasi berbelanja, karena semua barang belanjaan bisa dipesan melalui perantara media internet khususnya situs yang menjual belikan barang apa yang ingin di beli.

3. Pilihan yang ditawarkan sangat beragam, sehingga sebelum melakukan pemesanan kita dapat membandingkan semua produk dan harga yang ditawarkan oleh perusahaan.

4. Dengan perantara via internet pembeli dapat membeli barang di Negara lain secara online.

5. Harga yang ditawarkan sangat komfetitif, karena tingkat persaingan dari pelaku usaha melalui media internet sehingga mereka bersaing untuk menarik perhatian dengan cara menawarkan harga serendah-rendahnya (Sunarto, 2009 : 9)

Berdasarkan uraian di atas, maka penulis dapat menyimpulkan bahwa keuntungan jual beli via internet tidak hanya didapatkan oleh konsumen, penjual pun mendapatkan keuntunggan dimana penjual tidak perlu susah payah dalam menyewa toko untuk menjual dagangannya, disamping itu penjual dapat manfaakan teknologi dapat menjangkau kepada calon pembeli di seluruh dunia, sehingga biaya promosi akan lebih efesien. Di sisi lain, kelebihan yang mendasar yang ada pada transaksi jual beli via internet ini adalah si pembeli dan penjual sama-sama memiliki tingkat kejujuran dan kepercayaan yang tinggi sehingga keduanya tidak pernah merasa dirugikan.
Menurut, Sofie (2002 : 76), disamping keuntungan yang didapat penjual dan pembeli, adapun kerugianya adalah sebagai berikut:

a. Produk tidak dapat dicoba.

Dalam jual beli via internet produk yang ditawarkan adalah bermacam-macam dan beragam, dan semua produk tersebut tidak dapat dicoba, bila pembeli mencari pakaian, terutama pakaian atau yang lain maka pembeli tidak bisa mencoba. Sesungguhnya pengecer online menyediakan ukuran. Pembeli harus memberikan pertimbangan terhadap ukuran yang tercantum di toko berbasis web Tidak dapat berisi kain, tingkat kehalusan dan sebagainya.

b. Standar dari barang tidak sesuai

Salah satu kerugian yang di dapat pembeli dalam jual beli via internet adalah barang tidak sama dengan aslinya, di situs toko berbasis web yang ditampilkan adalah foto / gambar barang yang di tawarkan. Kesamaan dari barang foto / gambar yang kita lihat di sekitar monitor tidak bisa seratus persen persis sama. Mungkin yang mirip dengan barang awal hanya 75 sembilan puluh persen saja. Sudah sekitar pengaruh dari pencahayaan dan memantau pembeli komputer.

c. Pengiriman mahal.

Jual beli via internet yang terjadi melalui media elektronik yang berjauhan tentunya produk yang dibeli tidak selalu langsung kita dapat mengambil. Pemilik toko online masih memerlukan jasa pengiriman, dan yang menentukan pengiriman produk yang memiliki barangbarang tersebut pengiriman jasa JNE, TIKI, Pos Indonesia, dan sebagainya. 


\section{d. Risiko penipuan}

Dalam jual beli via intenet, toko berbasis web memang rentanakan penipuan. Pastikan belanja di website online yang dapat diandalkan. Bahayanya uang akan diteruskan ke penjual meskipun produk tidak dikirim dan tidak pernah dikirimkan selamanya.

\section{Metode Penelitian}

Penelitian ini merupakan penelitian deskriftif kualitatif. Tujuan penelitian ini dalah menafsirkan dan menuturkan data yang bersangkutan dengan situasi yang sedang terjadi, sikap/pandangan yang terjadi didalam masyarakat, pertentangan 2 keadaaan atau lebih, pengaruh terhadap suatu kondisi dll. Didalam penelitian deskriptif kualitatif ini, peneliti disini menggunakan kajian studi pustaka mencari informasi lewat buku, majalah, koran, dan literature lainnya untuk membentu sebuah landasan teori (Arikunto, 2006). Penelitian ini juga untuk menelaah sumber-sumber tertulis seperti jurnal ilmiah, buku referesni, literature, ensiklopedia, karangan ilmiah, karya ilmiah serta sumbersumber lain baik dalam bentuk tulisanatau dalam format digital yang relevan dan berhubungan dengan objek yang sedang diteliti. Adapun yang menjadi objek kajian penelitian ini adalah berupa teks-teks atau tulisan-tulisan yang menggambarkan dan memaparkan tentang bisnis/usaha online shop (shopping online) yang sedang menjamur di Indonesia.

\section{Hukum Jual Beli Online Menurut Hukum Negara (Undang-Undang )}

Dalam aturan perniagaan online, dapat diterapkan KUH Perdata. secara analogis, Dalam pasal 1313 KUH Perdata di jelaskan bahwa suatu persetujuan adalah suatu perbuatan dimana satu orang atau lebih mengikatkan dirinya terhadap satu orang lain atau lebih. Untuk sahnya suatu kontrak, kita harus melihat syarat-syarat yang diatur di dalam pasal 1320 KUH perdata yang menentukan bahwa syarat sah suatu perjanjian sebagai berikut;

1. Kesepakatan para pihak

2. Kecakapan untuk membuat perjanjian

3. Suatu hal tertentu; dan

4. Sesuatu sebab yang halal.

Apabila unsur pertama (kesepakatan) dan unsur kedua (kecakapan) tidak terpenuhi, maka kontrak tersebut dapat dibatalkan. Sedangkan apabila tidak terpenuhi unsur ketiga (suatu hal tertentu ) dan unsur keempat (suatu sebab yang halal) maka kontrak tersebut adalah batal demi hukum (Suhartono, 2010: 233).

Indonesia sebagai Negara hukum terhadap suatu perkara langsung berlandaskan dengan undang-undang. Semua itu dengan tujuan untuk kepentingan masyarakat Indonesia. maka jual beli online dapat dikaitkan dengan UU No.11 Tahun 2008 tentang Informasi Teknologi Elektronik (ITE). Pembahasan tentang ITE juga pernah terjadi pada Kasus Nyonya Prita tentang pencemaran nama baik sebuah Rumah sakit swasta di Jakarta melalui media elektronik berupa email yang terjerat dalam pasal 27 ayat 3 .

Menurut pasal 1 ayat 2 UU No. 11 Tahun 2008 tentang ITE menjelaskan tentang ransaksi elektronik adalah perbuatan hukum yang dilakukan dengan menggunakan Komputer, jaringan Komputer, dan/atau media elektronik lainnya (UU).

Dalam jual beli online banyak para konsumen mengeluh Karena tidak semua produk yang ditawarkan pada jual beli online itu sama persis dengan senyatanya, maka 
untuk melindungi kepentingan konsumen pada Pasal 28 ayat 1 UU No. 11 tahun 2008 tentang ITE menjelaskan bahwa setiap orang dengan sengaja dan tanpa hak menyebarkan berita bohong dan menyesatkan yang mengakibatkan kerugian konsumen dalam Transaksi Elektronik.

Adapun pidana bagi seseorang yang melakukan penipuan dalam media elektronik seperti dalam jual beli online dijelaskan dalam pasal 45 ayat 2 yang menyatakan:

Setiap orang yang memenuhi unsur sebagaimana dimaksud dalam Pasal 28 ayat (1) atau ayat (2) dipidana dengan pidana penjara paling lama 6 (enam) tahun dan/atau denda paling banyak Rp1.000.000.000,00 (satu miliar rupiah).

Pengawasan pemerintah terhadap suatu tindakan kriminal khususnya penipuan yang dilakukan dalam jual beli online harus segera ditindak lanjuti, mengingat banyak konsumen seperti sudah tidak percaya terhadap jual beli yang berlebel online padahal ini sangat membantu banyak kalangan selain meringankan penjual dalam memasarkan produknya, dalam jual beli online juga dapat mengurangi penggaguran di Indonesia karena mereka tidak harus mengeluarkan banyak modal untuk dapat berwirausaha.

\section{Hukum Jual Beli Online (Bisnis Online) Menurut Islam}

Dalam Islam berbisnis melalui online diperbolehkan selagi tidak terdapat unsurunsur riba, kezaliman, menopoli dan penipuan. Bahaya riba (usury) terdapat didalam Al-quran diantaranya di (QS. Al Baqarah [2]: 275, 279 dan 278, QS. Ar Rum [30]: 39, QS. An Nisa [4]: 131).

Riba itu ada dua macam: nasiah dan fadhl. Riba nasiah ialah pembayaran lebih yang disyaratkan oleh orang yang meminjamkan. Riba fadhl ialah penukaran suatu barang dengan barang yang sejenis, tetapi lebih banyak jumlahnya karena orang yang menukarkan mensyaratkan demikian, seperti penukaran emas dengan emas, padi dengan padi, dan sebagainya. Riba yang dimaksud dalam ayat ini riba nasiah yang berlipat ganda yang umum terjadi dalam masyarakat Arab zaman jahiliyah.

Rasulullah mengisyaratkan bahwa jual beli itu halal selagi suka sama suka (Antaradhin). Karena jual beli atau berbisnis seperti melalui online memiliki dampak positif karena dianggap praktis, cepat, dan mudah. Allah Swt berfirman dalam Alquran Surah Al Baqarah [2] : 275: “....Allah telah menghalalkan jual beli dan mengharamkan riba...". Al Bai' (Jual beli) dalam ayat termasuk didalamnya bisnis yang dilakukan lewat online. Namun jual beli lewat online harus memiliki syarat-syarat tertentu boleh atau tidaknya dilakukan.

Adapun syarat-syarat mendasar diperbolehkannya jual beli lewat online diantaranya:

1. Tidak melanggar ketentuan syari'at agama, seperti transaksi bisnis yang diharamkan, terjadinya kecurangan, penipuan dan menopoli.

2. Adanya kesepakatan perjanjian diantara dua belah pihak (penjual dan pembeli) jika terjadi sesuatu yang tidak diinginkan antara sepakat (Alimdha') atau pembatalan (Fasakh).

Sebagaimana yang telah diatur didalam Fikih tentang bentuk-bentuk option atau alternative dalam akad jual beli (Alkhiarat) seperti Khiar Almajlis (hak pembatalan di tempat jika terjadi ketidak sesuaian), Khiar Al'aib (hak pembatalan jika terdapat cacat), Khiar As-syarath (hak pembatalan jika tidak memenuhi syarat), 
Khiar At-Taghrir/Attadlis (hak pembatalan jika terjadi kecurangan), Khiar Alghubun (hak pembatalan jika terjadi penipuan), Khiar Tafriq As-Shafqah (hak pembatalan karena salah satu diantara duabelah pihak terputus sebelum atau sesudah transaksi), Khiar Ar-Rukyah (hak pembatalan adanya kekurangan setelah dilihat) dan Khiar Fawat Alwashaf (hak pembatalan jika tidak sesuai sifatnya).

3. Adanya kontrol, sanksi dan aturan hukum yang tegas dan jelas dari pemerintah (lembaga yang berkompeten) untuk menjamin bolehnya berbisnis yang dilakukan transaksinya melalui online bagi masyarakat.

Jika bisnis lewat online tidak sesuai dengan syarat-syarat dan ketentuan yang telah dijelaskan di atas, maka hukumnya adalah "Haram" tidak diperbolehkan. Kemaslahatan dan perlindungan terhadap umat dalam berbisnis dan usaha harus dalam perlindungan negara atau lembaga yang berkompeten. Agar tidak terjadi hal-hal yang membawa kemudratan, penipuan dan kehancuran bagi masyarakat dan negaranya.

Bisnis online sama seperti bisnis offline. Ada yang halal ada yang haram, ada yang legal ada yang ilegal. Hukum dasar bisnis online sama seperti akad jual beli dan akad as-salam, ini diperbolehkan dalam Islam. Adapun keharaman bisnis online karena beberapa sebab :

1) Sistemnya haram, seperti money gambling. Judi itu haram baik di darat maupun di udara (online), 2) Barang/jasa yang menjadi objek transaksi adalah barang yang diharamkan, seperti narkoba, video porno, online sex, pelanggaran hak cipta, situs-situs yang bisa membawa pengunjung ke dalam perzinaan. 3) Karena melanggar perjanjian (TOS) atau mengandung unsur penipuan. 4) Dan lainnya yang tidak membawa kemanfaatan tapi justru mengakibatkan kemudharatan.
Sebagaimana

menyebutkan:
Fikih "Alahkam Tattabi" peraturan] bertujuan untuk kemaslahatan". Kaidah lain ada menyebutkan: "I'tibar Almashalih Wadar'ul Mafasid; Mengutamakan Kemaslahatan Dan Menjauhkan Kerusakan “. Alquran juga menyebutkan dalam Surah Almuthaffifin [83]: 1-3 : "1. Kecelakaan besarlah bagi orang-orang yang curang (dalam berbisnis), 2. (yaitu) orang-orang yang apabila menerima takaran dari orang lain mereka minta dipenuhi, 3. Dan apabila mereka menakar atau menimbang untuk orang lain, mereka mengurangi".

Makna kata "Wail" (telaga neraka jahannam; kalmat hardik; Celaka) pada ayat Qur'an di atas, menunjukkan bahwa Allah Swt melaknat bagi orang yang menjalankan bisnis dengan kecurangan (Lilmuthaffifin). Ayat Alqur'an dan kaidah Fikih di atas tegas menganjurkan dalam berbisnis harus adanya kejujuran, adil, tidak saling mencurangi dan harus adanya payung hukum yang tegas dan jelas yang bertujuan untuk kemaslahatan masyarakat, negara dan umat.

Langkah-langkah yang dapat kita tempuh agar jual beli secara online diperbolehkan, halal, dan sah menurut syariat islam:

1) Produk Halal. Kewajiban menjaga hukum halal-haram dalam objek perniagaan tetap berlaku, termasuk dalam perniagaan secara online, mengingat Islam mengharamkan hasil perniagaan barang atau layanan jasa yang haram, sebagaimana ditegaskan dalam hadis: "Sesungguhnya bila Allah telah 
mengharamkan atas suatu kaum untuk memakan sesuatu, pasti Ia mengharamkan pula hasil penjualannya." (HR Ahmad, dan lainnya). Boleh jadi ketika berniaga secara online, rasa sungkan atau segan kepada orang lain sirna atau berkurang. Tapi Anda pasti menyadari bahwa Allah 'Azza wa Jalla tetap mencatat halal atau haram perniagaan Anda.

2) Kejelasan Status. Di antara poin penting yang harus Anda perhatikan dalam setiap perniagaan adalah kejelasan status Anda. Apakah sebagai pemilik, atau paling kurang sebagai perwakilan dari pemilik barang, sehingga berwenang menjual barang. Ataukah Anda hanya menawaran jasa pengadaan barang, dan atas jasa ini Anda mensyaratkan imbalan tertentu. Ataukah sekadar seorang pedagang yang tidak memiliki barang namun bisa mendatangkan barang yang Anda tawarkan.

3) Kesesuaian Harga Dengan Kualitas Barang. Dalam jual beli online, kerap kali kita jumpai banyak pembeli merasa kecewa setelah melihat pakaian yang telah dibeli secara online. Entah itu kualitas kainnya, ataukah ukurang yang ternyata tidak pas dengan badan. Sebelum hal ini terjadi kembali pada Anda, patutnya anda mempertimbangkan benar apakah harga yang ditawarkan telah sesuai dengan kualitas barang yang akan dibeli. Sebaiknya juga Anda meminta foto real dari keadaan barang yang akan dijual.

4) Kejujuran Anda. Berniaga secara online, walaupun memiliki banyak keunggulan dan kemudahan, namun bukan berarti tanpa masalah. Berbagai masalah dapat saja muncul pada perniagaan secara online. Terutama masalah yang berkaitan dengan tingkat amanah kedua belah pihak.

Bisa jadi ada orang yang melakukan pembelian atau pemesanan. Namun setelah barang Anda kirim kepadanya, ia tidak melakukan pembayaran atau tidak melunasi sisa pembayarannya. Bila Anda sebagai pembeli, bisa jadi setelah Anda melakukan pembayaran, atau paling kurang mengirim uang muka, ternyata penjual berkhianat, dan tidak mengirimkan barang. Bisa jadi barang yang dikirim ternyata tidak sesuai dengan apa yang ia gambarkan di situsnya atau tidak sesuai dengan yang Anda inginkan.

\section{Kesimpulan}

Berbisnis melalui online satu sisi dapat memberi kemudahan dan menguntungkan bagi masyarakat. Namun kemudahan dan keuntungan itu jika tidak diiringi dengan etika budaya dan hukum yang tegas akan mudah terjebak dalam tipu muslihat, saling mencurangi dan saling menzalimi. Disinilah Islam bertujuan untuk melindungi umat manusia sampai kapanpun agar adanya aturan-aturan hukum jual beli dalam Islam yang sesuai dengan ketentuan syari'at agar tidak terjebak dengan keserakahan dan kezaliman yang meraja lela. Transaksi bisnis lewat online jika sesuai dengan aturan-aturan yang telah disebut di atas akan membawa kemajuan bagi masyarakat dan negara.

Ketika kita terjun ke bisnis online, banyak sekali godaan dan tantangan bagaimana kita harus berbisnis sesuai dengan koridor Islam. Maka dari itu kita harus lebih berhati-hati. Jangan karena ingin mendapat keuntungan yang banyak lalu menghalalkan segala macam cara. Selama kita berbisnis online sesuai dengan prinsip-prinsip Islam dan bermanfaat 
bagi orang lain, tentunya keuntungan yang didapat akan berkah.

Sebagaima telah disebutkan di atas, hukum asal mu'amalah adalah al-ibaahah (boleh) selama tidak ada dalil yang melarangnya. Namun demikian, bukan berarti tidak ada rambu-rambu yang mengaturnya. Transaksi online diperbolehkan menurut Islam selama tidak mengandung unsur-unsur yang dapat merusaknya seperti riba, kezhaliman, penipuan, kecurangan dan yang sejenisnya serta memenuhi rukun-rukun dan syarat-syarat didalam jual belinya. Transaksi online dibolehkan menurut Islam berdasarkan prinsip-prinsip yang ada dalam perdagangan menurut Islam, khususnya dianalogikan dengan prinsip transaksi as-salam, kecuali pada barang/jasa yang tidak boleh untuk diperdagangkan sesuai syariat Islam.

\section{Daftar Pustaka}

Arikunto, Suharsimi. 2006. Prosedur Penelitian: Suatu Pendekatan Praktik. Jakarta: Rineka Cipta

Abdulkadir Muhammad. 1999. Hukum Perusahaan Indonesia. PT. Citra Aditya Bakti: Bandung.

Hidayat, Enang. 2015. Fiqih Jual Beli. Bandung: PT. Remaja Rosdakarya.

Ihsan, Ghufron, M.A. 2008. Fiqh Muamalah. Jakarta : Prenada Media Grup
Sofie, Yusuf. 2002. Pelaku Usaha Konsumen dan Tindak Pidana Korporasi. Jakarta: Galia Ilmu

Suhartono, 2010. Perniagaan online Syariah: suatu Kajian dalam prespektif Hukum perikatan Islam. Jurnal Muqtasid (Jurnal Ekonomi dan Perbankan Syari'ah)

Suherman, Ade Manan. 2009. Aspek Hukum Dalam Ekonomi Global. Jakarta: Ghalia Indonesia.

Suhrawardi Lubis. 2000. Hukum Ekonomi Islam. Sinar Grafika Offset:Jakarta.

Sunarto, Andi. 2009. Seluk Beluk ECommerce. Yogyakarta: Gaya Ilmu.

Suryodiningrat, R.M. 1996. Perikatanperikatan Bersumber Perjanjian. Bandung: Tarsito.

Tho'in, Muhammad. 2016. Larangan Riba Dalam Teks dan Konteks (Studi Atas Hadits Riwayat Muslim Tentang Pelaknatan Riba. Jurnal Ilmiah Ekonomi Islam, LPPM STIE AAS Surakarta. Vol. 2 No. 2, Juli 63-72.

Urnomo, W.A. 2000. Konsumen dan Transaksi E-Commerce. Jakarta: Yayasan Lembaga Konsumen Indonesia. 